University of Nebraska - Lincoln

DigitalCommons@University of Nebraska - Lincoln

$11-24-2006$

\title{
Agronomic and quality effects in winter wheat of a gene conditioning resistance to wheat streak mosaic virus
}

\author{
L. A. Divis \\ USDA-ARS
}

R. A. Graybosch

USDA-ARS, bob.graybosch@ars.usda.gov

C. J. Peterson

Oregon State University

P. Stephen Baenziger

University of Nebraska-Lincoln, pbaenziger1@unl.edu

G. L. Hein

University of Nebraska-Lincoln, ghein1@unl.edu

See next page for additional authors

Follow this and additional works at: https://digitalcommons.unl.edu/usdaarsfacpub

Part of the Agricultural Science Commons

Divis, L. A.; Graybosch, R. A.; Peterson, C. J.; Baenziger, P. Stephen; Hein, G. L.; Beecher, B. B.; and Martin, T. J., "Agronomic and quality effects in winter wheat of a gene conditioning resistance to wheat streak mosaic virus" (2006). Publications from USDA-ARS / UNL Faculty. 144.

https://digitalcommons.unl.edu/usdaarsfacpub/144

This Article is brought to you for free and open access by the U.S. Department of Agriculture: Agricultural Research Service, Lincoln, Nebraska at DigitalCommons@University of Nebraska - Lincoln. It has been accepted for inclusion in Publications from USDA-ARS / UNL Faculty by an authorized administrator of DigitalCommons@University of Nebraska - Lincoln. 


\section{Authors}

L. A. Divis, R. A. Graybosch, C. J. Peterson, P. Stephen Baenziger, G. L. Hein, B. B. Beecher, and T. J. Martin 


\title{
Agronomic and quality effects in winter wheat of a gene conditioning resistance to wheat streak mosaic virus
}

\author{
L. A. Divis · R. A. Graybosch · C. J. Peterson • \\ P. S. Baenziger - G. L. Hein - B. B. Beecher · \\ T. J. Martin
}

Received: 7 December 2005 / Accepted: 12 April 2006

(C) Springer Science + Business Media B.V. 2006

\begin{abstract}
Wheat streak mosaic virus (WSMV) is one of the most important diseases limiting winter wheat (Triticum aestivum L.) production in the western Great Plains of North America. There is no known effective WSMV resistance within the primary gene pool of wheat. However, a resistance gene (Wsml) has been transferred to wheat from a perennial relative, intermediate wheat-grass [Thinopyrum intermedium (Host)
\end{abstract}

Joint contribution of the United States Department of Agriculture, Agricultural Research Service and the Department of Agronomy, University of Nebraska-Lincoln as Journal Series Paper No. 15066. Mention of firm names or trade products does not imply that they are endorsed or recommended by the USDA or the University of Nebraska over other firms or products not mentioned.

L. A. Divis · R. A. Graybosch

USDA-ARS, Department of Agronomy \& Horticulture,

University of Nebraska, Lincoln, NE 68583, USA

\section{J. Peterson}

Department of Crop and Soil Sciences, Oregon State

University, Corvallis, OR 97331, USA

P. S. Baenziger · G. L. Hein

University of Nebraska, Lincoln, NE 68583, USA

B. B. Beecher

University of Nebraska, Lincoln, NE 68583, USA;

Current address: USDA-ARS, Washington State

University, Pullman, WA 99164, USA

\section{T. J. Martin}

Kansas State University, Agriculture Research

Center-Hays, 1232 240th Ave, Hays, KS 67601, USA
Barkworth \& DR Dewey]. Nebraska-adapted winter wheat lines carrying Wsml were used to characterize the effects of this alien introgression on agronomic and quality traits. Sister-lines from six breeding populations were evaluated under virus-free conditions, and under a naturally occurring viral infection. In uninfected locations, no significant difference for grain yield was detected between resistant (R) and susceptible (S) lines, when averaged over populations, but resistant lines had significantly higher test weights. Within populations, significantly higher grain yield was observed only in population 1, while significantly higher test weights occurred in populations 1, 2, 5 and 6 . At the infected location, resistant lines were significantly higher in yield in five of six populations. In two of six populations, susceptible lines were significantly higher in bread loaf volume and bake mix time, while in the remaining populations, no significant quality differences were observed. As the Wsml gene provided yield advantages under viral infection, and there was no yield detriment in the absence of the virus, its deployment in hard winter wheat cultivars merits consideration.

Keywords Triticum aestivum - Wheat streak mosaic virus $\cdot$ Wsm- 1 - Resistance gene $\cdot$ Agronomic and quality effects

\section{Introduction}

Winter wheat (Triticum aestivum L.) producers of the Great Plains region of North America yearly contend 
with the potentially devastating crop losses caused by wheat streak mosaic virus (WSMV). WSMV is spread via the wheat curl mite (WCM, Aceria tosichella Kiefer), the only known natural vector. Severe WSMV infection can result in complete crop failure. Factors contributing to the extent of damage are the timing of the infection, and temperatures and other environmental stresses during infection. Fall infections result in more severe yield depression than spring infestations (Hunger, 2004).

There is no known highly effective WSMV resistance within the primary gene pool of wheat. However, there is resistance to WSMV in some perennial wheat relatives. A resistance gene (Wsml) was identified and transferred from intermediate wheat-grass [Thinopyrum intermedium (Host) Barkworth \& DR Dewey] to wheat to limit infection by the virus and WCM colonization (Friebe et al., 1996). Transfer of this resistance traces to crosses between wheat and intermediate wheat-grass produced more than three decades ago (Wells et al., 1973, 1982). Subsequent breeding led to the development of wheat lines with Wsml and the potential to prevent major economic losses. However, many derived lines suffered from poor bread-making quality or agronomic properties (Seifers et al., 1995), perhaps due to negative epistatic effects of Wsml or closely linked genes.

Previous research on the agronomic and quality effects of Wsml has been conducted using spring wheats (Baley et al., 2001; Sharp et al., 2002) in the Northwestern United States. Baley et al. (2001) compared the agronomic performance of resistant to susceptible lines of spring wheat populations under both inoculated and non-inoculated conditions. They found Wsml provided a benefit in the presence of virus and had no detrimental effects on end use quality or other agronomic traits. Sharp et al. (2002) compared classical and transgenic spring wheat cultivars resistant to mechanical inoculation of WSMV. They found that while Wsml provides the most effective resistance to WSMV, significant yield penalties were observed in the absence of the virus.

Wheat producers desire to seed cultivars carrying natural disease resistance, but not if the introgressed trait results in yield losses when the pathogen is absent. The present study used Nebraska-adapted winter wheat sister-lines from six genetically diverse populations to evaluate any potential negative effects of Wsml. The objectives were to determine the effects of Wsml on yield and quality of winter wheat and to identify high yielding resistant lines for future testing.

\section{Materials and methods}

Plant materials and virus inoculation

Materials used in the study were derived from six breeding populations (Table 1) produced via matings of KS91H174 and KS91H184, two Kansas-adapted lines carrying Wsml, with various Nebraska-adapted lines. KS91H174 and KS91H184 both were derived from CI 17884, a WSMV resistance line carrying Wsm- 1 on a chromosome arm translocated from $T$. intermedium to wheat (Wells et al., 1982). Ninety-six heads were selected from each of either $F_{5}$ (populations 1-3) or $F_{3}$ (populations 4-6) bulk populations. Seed from heads was divided and planted in paired $1 \mathrm{~m}$ rows at Lincoln, NE in September 1999. Susceptible ('Tomahawk') and resistant (KS95H102) controls, were distributed every fifth and twelfth rows, respectively, amongst the paired rows. One row of each pair was mechanically inoculated with WSMV using a siphon-type Speedaire spray gun $(2 \mathrm{Z} 366 \mathrm{E})$ with a $1.65 \mathrm{~mm}$ nozzle size. A five hp, gas-powered, wheelbarrow air compressor fitted with a $15.25 \mathrm{~m} 19 \mathrm{~mm}$ air hose, powered the spray

Table 1 Pedigrees of populations segregating for Wsm-1

\begin{tabular}{ll}
\hline Population & Pedigrees \\
\hline Population 1 & CO850034//T-57/5*TAM107/3/(KS91H174/RBL//KS91HW29/3/Vista) \\
Population 2 & Yuma//T-57/3/Lamar/4/4*Yuma/5/(KS91H184/Arlin 'S'//KS91HW29/3/NE89526) \\
Population 3 & Yuma//T-57/3/CO850034/4/4*Yuma/5/(KS91H184/Arlin 'S'//KS91HW29/3/NE89526) \\
Population 4 & M08/Redland//KS91H184/3*RioBlanco \\
Population 5 & M08/NE94406 (=NE86582//84MC29/NE82583)//KS91H184/3*RioBlanco \\
Population 6 & M08/Redland//KS91H184/3*RioBlanco \\
\hline
\end{tabular}


gun. The unsprayed row of each pair was retained as a control to facilitate classification of resistance. Susceptible lines demonstrated both yellow-green leaf phenotypes and stunted growth, relative to unsprayed control rows.

The original inoculant was obtained by growing seedlings of 'Arapahoe' infected with the Sidney 81 strain (obtained from Drs. Roy French and Drake Stenger, USDA-ARS, Lincoln, NE). Eight flats of Arapahoe were planted and inoculated by thumb and forefinger, at the 2-3 leaf stage. After 10 days, seedlings were harvested and placed in $\mathrm{a}-20^{\circ} \mathrm{C}$ freezer. Fresh inoculum was prepared the day of the spraying treatments. To make one 21 flask of inoculum, $40 \mathrm{~g}$ of leaf material was used. Leaf material was ground in a Waring blender in $20 \mathrm{~g}$ increments with $400 \mathrm{mls}$ of deionized distilled water. The slurry was strained through eight layers of cheesecloth into a $2 \mathrm{~L}$ volumetric flask packed in ice. To facilitate entry of the virus, $20 \mathrm{~g}$ Celite was added to the flask. When applying the virus with the spray gun, the solution was stirred constantly to ensure the Celite remained in solution.

In the spring of 2000, lines were scored as resistant or susceptible based on visual symptoms (yellow-green mottling of leaves and stunting). To verify these phenotypic scores, lines were re-seeded at Hays, KS in the fall of 2001. Lines, along with resistant and susceptible checks, were planted in unreplicated $1 \mathrm{~m}$ rows. Plants were infected with naturally occurring WSMV by native WCM reared on adjacent early-planted wheat. In the spring of 2002, the lines were rated as resistant or susceptible. Subsequent to the conduct of replicated field trials (see below), selected lines were re-verified by using a similar approach at Scottsbluff, NE, during the 2004 and 2005 crop years. At Scottsbluff, lines were seeded in replicated $3 \mathrm{~m}$ rows.

During the conduct of the replicated field trials (see below), a naturally occurring infestation with WSMV was encountered at Sidney, NE. Lines also were rated as resistant and susceptible at this location.

\section{Replicated field experiments}

The study was planted in the fall of 2002 as an augmented design (Federer et al., 1975). The entries randomly were selected from the six populations (Table 1). Populations 1-3 were composed of $\mathrm{F}_{5}$-derived $\mathrm{F}_{8}$ lines; entries in populations $4-6$ were $\mathrm{F}_{3}$-derived $\mathrm{F}_{6}$ lines. Lines were classified as resistant only if consistently scored so at Lincoln, Hays and Sidney. From each of the six populations, no less than five and no more than seven entries each of resistant and susceptible lines were chosen at random. Resistant and susceptible checks were planted at random among the entries. Checks were replicated while resistant and susceptible lines were unreplicated at each location. The checks consisted of three susceptible cultivars (Millennium, Tomahawk and Wesley) and three experimental lines (KS96HW10-1, KS96HW10-3 and KS95H102) carrying the Wsml resistance gene. Entries were seeded in 4 row, $4.5 \mathrm{~m}$ plots, trimmed to $2.5 \mathrm{~m}$ before harvest. Grain yield, test weight (grain volume weight), plant heights and days (from 1/1) to heading were recorded. The locations were Grant, Lincoln, McCook, Mead, North Platte and Sidney, NE. The Sidney location, due to the natural infection by WSMV, was analyzed as a separate experiment.

Analysis of variance and paired $t$-tests in all possible combinations were used to test for differences among checks. Mean squares from the analysis of check lines were used to compute statistical contrasts (Steel\& Torrie, 1980) comparing resistant verses susceptible lines, both within each population and averaged across populations. Statistical significance of contrasts was declared via $F$-tests. All statistical analyses of the data were conducted using PROC GLM in SAS (SAS Version 8.02).

\section{DNA marker screening}

All randomly selected sister-lines and replications of checks, were screened for a DNA marker linked to the Wsml resistance gene (Talbert et al., 1996). For each entry, eight to ten seed were aligned in Cyg germination pouches obtained from Mega International (West Saint Paul, MN), and grown for 10 days in an incubation chamber set at $27^{\circ} \mathrm{C}$. The seedling leaf tissue, 1.5 to 2 inches in length, was harvested and the DNA was isolated and extracted as per procedures described in Dweikat et al. (2002).

Primers STSJ15L and STSJ15R (Talbert et al., 1996) were purchased from Invitrogen Life Technologies (Carlsbad, CA). The Polymerase Chain Reaction (PCR) method was as described in Talbert et al. (1996). The amplified products were fractionated on a $1.5 \%$ agarose gel containing ethidium bromide. The gels were then placed on an ultraviolet light box and results recorded. Resistant lines were confirmed as such 
by the presence of a $420 \mathrm{bp}$ PCR product not found in the susceptible lines (Talbert et al., 1996).

High-performance capillary electrophoresis 1BL.1RS screen

Based on pedigrees, some lines were suspected as carriers of the 1BL.1RS wheat-rye (Secale cereale L.) chromosomal translocation, known to have a negative impact on wheat breadmaking quality (Lee et al., 1995; Graybosch, 2001). High-performance capillary electrophoresis of grain proteins was used to identify lines carrying the translocation (Lookhart et al., 1996). A Beckman Coulter (Fullerton, CA) P/ACE System 5500 was used to separate all extracts. Screening for the presence of the 1RS gene was completed to check for possible confounding effects in baking quality assays.

Quality analyses

To obtain samples large enough for milling, composite samples were produced, using equal amounts of seed from Lincoln, Mead, McCook and North Platte locations. Samples were tempered to $15 \%$ moisture content and milled to flour using a Buhler experimental flour mill. Samples were baked in the University of Nebraska wheat quality lab (UNL lab) using a 100 gm straightdough pup loaf procedure (method 10-09, AACC 1983) with no added oxidants. The following variables were recorded: bake absorption (\%), bake mix time (min), loaf volume (ml) and loaf grain (0-13). Loaf grain was rated on a scale of $0=$ very poor, to $13=$ excellent. Duplicate loaves were baked and average scores were reported. A completely random statistical design was used to evaluate quality variables. Means of resistant vs susceptible lines were compared within populations. Mean responses of resistant and susceptible lines also were compared to means of the check cultivars. Mean squares from analysis of variance were computed, and mean comparisons in all possible combinations were evaluated for statistical significance using paired $t$-tests calculated for un-equal sample means (Steel \& Torrie, 1980).

\section{Results and discussion}

Of the materials inititally selected, 63 lines demonstrated consistent resistant responses and were positive for the presence of the $420 \mathrm{bp}$ PCR product linked to Wsm-1 (Talbert et al., 1996) while 82 lines consistently were rated susceptible and did not produce the $420 \mathrm{bp}$ fragment. The remaining lines displayed questionable phenotypes or were obviously segregating. Thirty-six resistant and 34 susceptible lines subsequently were selected at random for inclusion in evaluation of agronomic and quality traits.

The analysis of variance (Table 2) revealed significant differences for yield, test weight and heading date among the five uninfected locations and amongst the checks. Wesley was the highest yielding check cultivar, with significantly higher grain yields than the three Wsm1-carrying checks (Table 3). Test weights of these three resistant checks were, however, significantly greater than those of the three susceptible checks, even in these uninfected locations.

Averaged over populations, contrasts of resistant vs susceptible lines from the uninfected locations showed no significant difference in grain yield (Table 2). A significant difference in grain yield was observed only within population 1 (Table 2), with the susceptible lines demonstrating significantly higher mean grain yield (Table 4). Test weights were significantly higher in resistant lines, both across and within 4 of the 6 populations (Tables 2 and 4). The significant differences in test weight amongst these populations, and the significantly higher test weights observed in resistant vs susceptible checks, might indicate that Wsm1, or closely linked genes, affects seed shape, weight or seed packing volume. Plant heights were significantly greater in susceptible lines, both averaged across populations, and within two populations (Tables 2 and 4). No differences in days to heading were observed.

Under a natural epidemic of WSMV at Sidney (Table 5) one resistant check, KS96HW102 and one susceptible check, Millennium, had significantly higher grain yields than all other checks. The two remaining resistant checks, KS96HW10-1 and KS96HW10-3 had significantly higher grain yields than the susceptible lines Tomahawk and Wesley. Millennium does not carry Wsml, but consistently has demonstrated a moderate tolerance to WSMV (personal observations, P.S. Baenziger \& G.L. Hein). The response of Millennium under this natural epidemic, as compared to Tomahawk and Wesley, indicates there exists differential tolerances amongst wheats lacking Wsml. Placing Wsml in genetic backgrounds similar to Millennium could perhaps further enhance the resistance response. Resistant 
Table 2 Mean squares from the analysis of variance of checks and contrasts of WSMV resistant vs. susceptible sister lines from six populations grown at five Nebraska locations

\begin{tabular}{lrcccc}
\hline Source of variation & $\mathrm{df}^{\mathrm{a}}$ & Grain yield & Test weight & Plant height & Days (from 1/1) to heading \\
\hline Location & 4 & $43348741.50^{*}$ & $210.66^{*}$ & $4917.13^{*}$ & $103.71^{*}$ \\
Check & 5 & $4872159.60^{*}$ & $38.43^{*}$ & 322.82 & $23.26^{*}$ \\
Loc*Check & 20 & 1093712.80 & 3.06 & 39.87 & 9.38 \\
& \multicolumn{5}{c}{ Contrasts: Resistant vs Susceptible } \\
Overall & 1 & 4337659.6 & $80.06^{*}$ & $893.36^{*}$ & 1.3 \\
Population 1 & 1 & $6160343.31^{*}$ & $26.04^{*}$ & $770.51^{*}$ & 0.07 \\
Population 2 & 1 & 653330.13 & $21.04^{*}$ & 13.01 & 26.04 \\
Population 3 & 1 & 918560.43 & 4.82 & $552.79^{*}$ & 0.12 \\
Population 4 & 1 & 470468.45 & 2.46 & $154.84^{*}$ & 3.94 \\
Population 5 & 1 & 26853.89 & $29.85^{*}$ & $131.72^{*}$ & 15.04 \\
Population 6 & 1 & 122.13 & $45.49^{*}$ & 0.39 & 20.04 \\
Error & $115^{\mathrm{b}}$ & 246310.4 & 1.65 & 27.67 & 1.21 \\
\hline
\end{tabular}

${ }^{\mathrm{a}} \mathrm{df}=$ degrees of freedom.

${ }^{\mathrm{b}} \mathrm{df}$ : yield, test weight and heading date $=115$; plant height $=74$

* Significant at $P=0.05$

Table 3 Mean grain yield, testweight, plant height and heading date for WSMV resistant and susceptible check varieties

\begin{tabular}{|c|c|c|c|c|c|c|}
\hline Entry & Class $^{\mathrm{a}}$ & No. ${ }^{b}$ & Yield (kg/ha) & $\begin{array}{l}\text { Test weight } \\
\text { (kghl) }\end{array}$ & $\begin{array}{l}\text { Plant height } \\
(\mathrm{cm})\end{array}$ & $\begin{array}{l}\text { Heading } \\
\text { Date }^{c}\end{array}$ \\
\hline KS96HW10-1 & $\mathrm{R}$ & 15 & $2900.8^{B}$ & $78.6^{\mathrm{A}}$ & $66^{\mathrm{C}}$ & $144^{\mathrm{AB}}$ \\
\hline KS96HW10-3 & $\mathrm{R}$ & 15 & $2840.3^{\mathrm{B}}$ & $78.3^{\mathrm{AB}}$ & $67^{\mathrm{BC}}$ & $144^{\mathrm{AB}}$ \\
\hline KS95H102 & $\mathrm{R}$ & 25 & $2826^{C}$ & $77.2^{\mathrm{B}}$ & $69^{\mathrm{BC}}$ & $145^{\mathrm{AB}}$ \\
\hline Millenium & $\mathrm{S}$ & 25 & $3380^{\mathrm{ABC}}$ & $76.2^{\mathrm{C}}$ & $76^{\mathrm{A}}$ & $146^{\mathrm{A}}$ \\
\hline Tomahawk & $\mathrm{S}$ & 35 & $3410^{\mathrm{AB}}$ & $75.6^{\mathrm{C}}$ & $69^{\mathrm{BC}}$ & $142^{\mathrm{B}}$ \\
\hline Wesley & $\mathrm{S}$ & 30 & $3935^{\mathrm{A}}$ & $75.6^{\mathrm{C}}$ & $69^{\mathrm{B}}$ & $144^{\mathrm{AB}}$ \\
\hline
\end{tabular}

Means followed by the same letter were not significantly different at $P=0.05$

${ }^{a}$ Class: $\mathrm{R}=$ plants with the WSMV resistance gene; $\mathrm{S}=$ virus susceptible plants

${ }^{\mathrm{b}}$ No. $=$ number of plots

${ }^{\mathrm{c}}$ Number of days after January 1 checks KS96HW10-1, KS96HW10-3 and KS95H102 again produced significantly higher test weights than Millennium, Tomahawk and Wesley. Tomahawk was significantly lower in test weight than all other checks.

Resistant lines demonstrated significantly higher grain yields under the WSMV epidemic at Sidney, both across all populations, and within five of the six populations (Table 6). Susceptible lines in the one exceptional population also may have had some tolerance to viral infection. Average grain yields of the resistant line under this viral infection were $1797 \mathrm{~kg} / \mathrm{ha}$, or $37 \%$ higher than susceptible lines grown at the same location. Test weights were significantly greater in resistant lines, both across and within all populations. Baley et al. (2001) observed a similar effect in spring wheats.

Within populations, some significant differences in quality were observed between resistant and susceptible sibs (Table 7). In population 1, mean flour protein concentration, bake mix time, and loaf volume of the susceptible lines was significantly greater than the mean of the resistant lines. The differences in bake mix time and loaf volume might not necessarily derive from the presence of Wsml per se, but might be a consequence of the statistically lower flour protein concentration. In population 6 , the mean bake mix time and loaf volume of the susceptible lines also exceeded those of resistant lines, and no differences in protein 
Table 4 Mean grain yield, test weight, plant height and heading date for WSMV resistant and susceptible lines grown at five Nebraska locations

\begin{tabular}{|c|c|c|c|c|c|c|c|}
\hline \multirow[b]{2}{*}{ Pop. } & \multirow[b]{2}{*}{ Class $^{\mathrm{a}}$} & \multirow[b]{2}{*}{ No. ${ }^{b}$} & \multicolumn{2}{|c|}{ Yield (kg/ha) } & \multirow{2}{*}{$\begin{array}{l}\text { Test weight } \\
\text { (kghl) }\end{array}$} & \multirow{2}{*}{$\begin{array}{l}\text { Plant height } \\
(\mathrm{cm})\end{array}$} & \multirow{2}{*}{$\begin{array}{l}\text { Heading date }^{\mathrm{c}} \\
(\text { days from } 1 / 1)\end{array}$} \\
\hline & & & Means & Ranges & & & \\
\hline \multirow[t]{2}{*}{ Overall } & $\mathrm{R}$ & 36 & 2879 & $2397-3485$ & $76.6^{*}$ & 66 & 145 \\
\hline & $\mathrm{S}$ & 34 & 3102 & $2397-3965$ & 75.5 & $70^{*}$ & 145 \\
\hline \multirow[t]{2}{*}{1} & $\mathrm{R}$ & 7 & 2424 & $2291-2568$ & $77.4^{*}$ & 62 & 147 \\
\hline & $\mathrm{S}$ & 6 & $2996^{*}$ & $2774-3156$ & 75.9 & $69^{*}$ & 147 \\
\hline \multirow[t]{2}{*}{2} & $\mathrm{R}$ & 6 & 3044 & $2728-3163$ & $77.3^{*}$ & 70 & 143 \\
\hline & $\mathrm{S}$ & 6 & 3243 & $2784-3660$ & 76.2 & 69 & 145 \\
\hline \multirow[t]{2}{*}{3} & $\mathrm{R}$ & 6 & 3253 & $3045-3485$ & 73.5 & 68 & 144 \\
\hline & $\mathrm{S}$ & 5 & 3512 & $3096-3965$ & 72.9 & $74^{*}$ & 144 \\
\hline \multirow[t]{2}{*}{4} & $\mathrm{R}$ & 5 & 2819 & 2396-3139 & 75.8 & 67 & 145 \\
\hline & $\mathrm{S}$ & 6 & 3004 & $2396-3231$ & 75.9 & 71 & 144 \\
\hline \multirow[t]{2}{*}{5} & $\mathrm{R}$ & 6 & 2881 & $2586-3329$ & $77.5^{*}$ & 65 & 144 \\
\hline & $\mathrm{S}$ & 6 & 2924 & 2619-3336 & 76.3 & 68 & 143 \\
\hline \multirow[t]{2}{*}{6} & $\mathrm{R}$ & 6 & 2981 & $2760-3255$ & $77.6^{*}$ & 66 & 144 \\
\hline & $\mathrm{S}$ & 5 & 2978 & $2745-3312$ & 75.6 & 66 & 146 \\
\hline
\end{tabular}

${ }^{\mathrm{a} C l a s s:} \mathrm{R}=$ resistant to WSMV; $\mathrm{S}=$ susceptible

${ }^{\mathrm{b}}$ No. $=$ number of lines

${ }^{\mathrm{c}}$ Number of days after January 1

*Designates significantly different means at $P=0.05$

Table 5 Mean grain yield and test weight for WSMV resistant and susceptible checks under infection at Sidney, NE

\begin{tabular}{lllll}
\hline Entry & Class $^{\mathrm{a}}$ & No. $^{\mathrm{b}}$ & ${\text { Yield }(\mathrm{kg} / \mathrm{ha})^{\mathrm{c}}}$ & Test weight $(\mathrm{kg} / \mathrm{hl})^{\mathrm{A}}$ \\
\hline KS96HW10-1 & $\mathrm{R}$ & 3 & $1550^{\mathrm{B}}$ & $77.2^{\mathrm{AC}}$ \\
KS96HW10-3 & $\mathrm{R}$ & 3 & $1739^{\mathrm{AB}}$ & $76.2^{\mathrm{AB}}$ \\
KS95H102 & $\mathrm{R}$ & 5 & $1931^{\mathrm{A}}$ & $76.1^{\mathrm{BC}}$ \\
Millennium & $\mathrm{S}$ & 5 & $1922^{\mathrm{A}}$ & $72.4^{\mathrm{D}}$ \\
Tomahawk & $\mathrm{S}$ & 7 & $1190^{\mathrm{C}}$ & $69.8^{\mathrm{E}}$ \\
Wesley & $\mathrm{S}$ & 6 & $1060^{\mathrm{C}}$ & $72.2^{\mathrm{D}}$ \\
\hline
\end{tabular}

${ }^{\mathrm{a} C l a s s:} \mathrm{R}=\mathrm{WSMV}$ resisitant; $\mathrm{S}=$ susceptible

${ }^{\mathrm{b}}$ No. $=$ number of lines

${ }^{\mathrm{c}}$ Means followed by the same letter were significantly different at $P=$ 0.05

concentration were detected. In the remaining four populations, however, mean responses of susceptible lines did not significantly exceed those of resistant lines, and, in some cases (Table 7) actually were significantly lower. If Wsml, or closely linked genes, has an effect on quality, the results were not consistent across genetic backgrounds, and resistant lines with acceptable to good quality were identified.

Amongst the checks (Table 7), Wesley had the highest average loaf volume and bake mix time, (a measure of dough strength). Wesley generally is considered a high quality wheat. Flour protein contents of Wesley were not significantly higher than those of the remaining check cultivars, and also were not significantly different than the mean flour protein concentration of the resistant lines from any of the six populations. Bake absorptions of resistant lines from populations 2 and 5 actually significantly exceeded those of Wesley, but loaf volumes of resistant lines of populations 2, 4, 5 and 6 were significantly lower than that of Wesley. Mean bake mix times of the resistant lines of all populations 
Table 6 Grain yield and test weight for WSMV resistant and susceptible lines at Sidney, NE, under viral infection a Popn = population

${ }^{\mathrm{b}}$ Class $=$ Resistant and susceptible plants

${ }^{\mathrm{c}}$ No. $=$ number of lines

${ }^{*}$ Values are significant at $P$ $=0.05$

\begin{tabular}{|c|c|c|c|c|c|}
\hline \multirow[b]{2}{*}{ Popn $^{\mathrm{a}}$} & \multirow[b]{2}{*}{ Class ${ }^{b}$} & \multirow[b]{2}{*}{ No. ${ }^{\mathrm{c}}$} & \multicolumn{2}{|c|}{ Yield (kg/ha) } & \multirow{2}{*}{$\begin{array}{l}\text { Test weight }(\mathrm{kg} / \mathrm{hl}) \\
\text { mean }\end{array}$} \\
\hline & & & mean & Range & \\
\hline \multirow[t]{2}{*}{ Overall } & $\mathrm{R}$ & 36 & $1797^{*}$ & 694-2364 & $76.3^{*}$ \\
\hline & $\mathrm{S}$ & 34 & 1311 & 484-1962 & 70.4 \\
\hline \multirow[t]{2}{*}{1} & $\mathrm{R}$ & 7 & $1963^{*}$ & 1774-2063 & $77.2^{*}$ \\
\hline & $\mathrm{S}$ & 6 & 1323 & 1086-1458 & 71.3 \\
\hline \multirow[t]{2}{*}{2} & $\mathrm{R}$ & 6 & 1733 & 694-2172 & $77.7^{*}$ \\
\hline & $\mathrm{S}$ & 6 & 1744 & $1612-1840$ & 72.0 \\
\hline \multirow[t]{2}{*}{3} & $\mathrm{R}$ & 6 & $2123^{*}$ & $1893-2368$ & $72.0^{*}$ \\
\hline & $\mathrm{S}$ & 5 & 1879 & 1833-1962 & 65.3 \\
\hline \multirow[t]{2}{*}{4} & $\mathrm{R}$ & 5 & $1699^{*}$ & 1236-1944 & $77.4^{*}$ \\
\hline & $\mathrm{S}$ & 6 & 1064 & $921-1227$ & 71.1 \\
\hline \multirow[t]{2}{*}{5} & $\mathrm{R}$ & 6 & $1683^{*}$ & 1361-2197 & $77.3^{*}$ \\
\hline & $\mathrm{S}$ & 6 & 1039 & $659-1291$ & 73.0 \\
\hline \multirow[t]{2}{*}{6} & $\mathrm{R}$ & 6 & $1539^{*}$ & $809-2228$ & $76.5^{*}$ \\
\hline & $\mathrm{S}$ & 5 & 837 & $485-1256$ & 68.6 \\
\hline
\end{tabular}

Table 7 Mean $^{\mathrm{a}}$ flour quality characteristics of WSMV resistant and susceptible check cultivars and experimental lines
${ }^{\mathrm{a}}$ Means followed by the same letter did not differ significantly at $\mathrm{p}=0.05$

${ }^{\mathrm{b}}$ Class: $\mathrm{R}=$ resistant; $\mathrm{S}=$ susceptible

$\mathrm{cFP}=$ flour protein

concentration, $14 \% \mathrm{mb}$;

$\mathrm{ABS}=$ flour water

absorption; BMT = bake

mix time; $\mathrm{LV}=$ loaf

volume; GRN = loaf grain,

$0=$ poor, $13=$ excellent

\begin{tabular}{llllllll}
\hline Line or population & Class $^{\mathrm{b}}$ & $\mathrm{N}$ & $\mathrm{FP}(\%)^{\mathrm{c}}$ & $\mathrm{ABS}(\%)$ & $\mathrm{BMT}(\mathrm{min})$ & $\mathrm{LV}(\mathrm{ml})$ & $\mathrm{GRN}(0-13)$ \\
\hline Wesley & $\mathrm{S}$ & 6 & $12.8 \mathrm{bc}$ & $61.0 \mathrm{bcd}$ & $6.3 \mathrm{a}$ & $998 \mathrm{ab}$ & $7 \mathrm{bc}$ \\
Tomahawk & $\mathrm{S}$ & 7 & $12.6 \mathrm{bc}$ & $61.4 \mathrm{ab}$ & $3.9 \mathrm{c}$ & $863 \mathrm{~d}$ & $7 \mathrm{bc}$ \\
Millennium & $\mathrm{S}$ & 5 & $12.3 \mathrm{~cd}$ & $61.8 \mathrm{ab}$ & $5.0 \mathrm{~b}$ & $916 \mathrm{~cd}$ & $8 \mathrm{ab}$ \\
KS96HW10-3 & $\mathrm{R}$ & 3 & $12.6 \mathrm{bc}$ & $62.0 \mathrm{ab}$ & $4.6 \mathrm{bc}$ & $955 \mathrm{bc}$ & $8 \mathrm{ab}$ \\
KS96HW10-1 & $\mathrm{R}$ & 3 & $12.5 \mathrm{bc}$ & $61.0 \mathrm{bcd}$ & $5.1 \mathrm{ab}$ & $978 \mathrm{bc}$ & $9 \mathrm{a}$ \\
KS95H012 & $\mathrm{R}$ & 5 & $13.2 \mathrm{a}$ & $62.6 \mathrm{ab}$ & $4.6 \mathrm{bc}$ & $906 \mathrm{~cd}$ & $7 \mathrm{bc}$ \\
1 & $\mathrm{R}$ & 7 & $12.6 \mathrm{bc}$ & $61.0 \mathrm{bcd}$ & $4.9 \mathrm{~b}$ & $950 \mathrm{bc}$ & $7 \mathrm{bc}$ \\
1 & $\mathrm{~S}$ & 6 & $13.2 \mathrm{a}$ & $60.2 \mathrm{~cd}$ & $6.1 \mathrm{a}$ & $1048 \mathrm{a}$ & $4 \mathrm{~d}$ \\
2 & $\mathrm{R}$ & 6 & $12.3 \mathrm{~cd}$ & $62.4 \mathrm{a}$ & $4.8 \mathrm{bc}$ & $938 \mathrm{~cd}$ & $9 \mathrm{a}$ \\
2 & $\mathrm{~S}$ & 6 & $11.9 \mathrm{~d}$ & $61.7 \mathrm{ab}$ & $4.4 \mathrm{bc}$ & $829 \mathrm{~d}$ & $7 \mathrm{bc}$ \\
3 & $\mathrm{R}$ & 6 & $12.7 \mathrm{~b}$ & $60.0 \mathrm{~d}$ & $5.5 \mathrm{ab}$ & $968 \mathrm{bc}$ & $8 \mathrm{ab}$ \\
3 & $\mathrm{~S}$ & 5 & $12.1 \mathrm{~cd}$ & $60.2 \mathrm{~cd}$ & $6.4 \mathrm{a}$ & $936 \mathrm{~cd}$ & $9 \mathrm{a}$ \\
4 & $\mathrm{R}$ & 6 & $12.5 \mathrm{bcd}$ & $61.7 \mathrm{ab}$ & $3.9 \mathrm{c}$ & $845 \mathrm{~d}$ & $6 \mathrm{c}$ \\
4 & $\mathrm{~S}$ & 6 & $12.5 \mathrm{bcd}$ & $61.0 \mathrm{bcd}$ & $4.6 \mathrm{bc}$ & $921 \mathrm{~cd}$ & $9 \mathrm{a}$ \\
5 & $\mathrm{R}$ & 6 & $12.7 \mathrm{~b}$ & $62.4 \mathrm{a}$ & $4.0 \mathrm{c}$ & $884 \mathrm{~cd}$ & $6 \mathrm{c}$ \\
5 & $\mathrm{~S}$ & 6 & $12.9 \mathrm{ab}$ & $62.0 \mathrm{ab}$ & $4.3 \mathrm{bc}$ & $909 \mathrm{~cd}$ & $7 \mathrm{bc}$ \\
6 & $\mathrm{R}$ & 6 & $12.4 \mathrm{~cd}$ & $61.6 \mathrm{ab}$ & $4.2 \mathrm{c}$ & $878 \mathrm{~d}$ & $7 \mathrm{bc}$ \\
6 & $\mathrm{~S}$ & 5 & $12.1 \mathrm{~cd}$ & $61.2 \mathrm{bc}$ & $5.1 \mathrm{ab}$ & $966 \mathrm{bc}$ & $8 \mathrm{ab}$ \\
\hline
\end{tabular}

were significantly lower than bake mix time of Wesley. Bake mix times and loaf volumes of Millennium and Tomahawk also were significantly lower than those of Wesley. Thus, while lines carrying Wsml have yet to be identified with the high quality characteristics of Wesley, WSMV lines with acceptable quality have been obtained. Variation also exists for quality characteristics, and no consistent negative responses, relative to susceptible lines of similar genetic background, were observed. Hence, the potential to breed WSMV resistant lines with superior quality seems evident. 
Capillary electrophoresis separation of grain storage proteins revealed approximately equal number of resistant and susceptible lines with and without the 1BL.1RS wheat-rye chromosomal translocation. In populations 1-3, no 1BL.1RS positive lines were detected. Populations 4, 5, and 6 did, however, contain some lines positive for 1BL.1RS. Among the resistant lines, population 4 had 3 of 5 lines with 1BL.1RS, population 5, 3 of 6 lines, and population 6,2 of 6 lines. In the susceptible lines, population 4 revealed 5 out of 6 lines positive for 1BL.1RS, population 5, 3 of 6 lines, and population 6, 2 of 5 lines. The higher flour protein value for population 1 was not due to 1BL.1RS, nor did 1BL.1RS explain any of the observed differences in quality between resistant and susceptible lines (data not shown). The presence of 1RS did not confer any additional resistance or tolerance to WSMV.

The lack of demonstrated yield penalties of Wsml in winter wheat grown in the absence of virus, and the yield advantage observed under the viral infection, suggest efforts to deploy this gene in cultivars are both desirable and necessary. Hypothetical financial losses of growing susceptible wheats in a year when the WSMV is present are large. To estimate these financial losses, the following assumptions were made: (1) in the absence of the virus, the resistant and susceptible lines are not significantly different in yield (as observed in the five uninfected locations), and (2) in the presence of the virus susceptible lines produced only $72.9 \%$ the grain yield (estimated using the overall yields from the Sidney location) of resistant lines. Calculations at hypothetical yield levels of $2000 \mathrm{~kg} / \mathrm{ha}, 2700 \mathrm{~kg} / \mathrm{ha}$, and $3300 \mathrm{~kg} / \mathrm{ha}$ demonstrated the yield losses would be 542 , 732 , and $894 \mathrm{~kg} / \mathrm{ha}$ loss respectively. At a typical price of $\$ 110$ (USD) per metric ton, savings resulting from planting of a resistant line would be approximately $\$ 59.62, \$ 80.52$, and $\$ 98.34$ per hectare, respectively. WSMV epiphytotics most often have a greater impact on yield than this example and total crop failure is common. In cases of total crop failure, the financial savings resulting from production of resistant lines would be substantial.

\section{Conclusions}

In the absence of virus, Wsml had no negative effect on grain yield, at least in the tested winter wheat pop- ulations. Large and significant increases in grain yield were demonstrated under a natural WSMV infection. In addition, significant advantages in test weight were observed, with and without the presence of WSMV. As test weight is used in the establishment of wheat grades at point of sale, this effect represents an additional source of financial savings for wheat producers. It is possible, therefore to selectively breed for desired agronomic traits and incorporate WSMV resistance from a wild relative of wheat. Quality characteristics were affected by the resistance gene, but not in all genetic backgrounds. Thus, rigorous quality testing at early generations is necessary with further breeding efforts using Wsml, but careful selection of appropriate genetic backgrounds for matings should help avoid quality defects.

\section{References}

American Association of Cereal Chemists (1983) Approved methods of the AACC. AACC, St. Paul, MN

Baley GJ, Talbert LE, Martin JM, Young MJ, Habernicht DK, Kushnak GD, Berg JE, Lanning SP, Bruckner PL (2001) Agronomic and end-use qualities of wheat streak mosaic virus resistant spring wheat. Crop Sci 41:1779-1784

Dweikat I, Zhang W, Ohm H (2002) Development of STS markers linked to Hessian fly resistance gene H6 in wheat. Theor Appl Genet 105:766-770

Federer WT, Raghavarao D (1975) On augmented designs. In Biometrics 31:29-35

Friebe B, Gill KS, Tuleen NA, Gill BS (1996) Transfer of wheat streak mosaic virus resistance from Agropyron intermedium into wheat. Crop Sci 36:857-861

Graybosch RA (2001) Uneasy unions: Quality effects of rye chromatin transfers to wheat. Journal of Cereal Science $33: 3-16$

Hunger R (2004) Wheat streak mosaic virus prevalent in Western Oklahoma and the Panhandle. Plant Disease and Insect Advisory 3(7), Oklahoma State University, http://entoplp.okstate.edu/Pddl/advisory.htm

Lee JH, Graybosch RA, Peterson CJ (1995) Quality and biochemical effects of a BL/1RS whet-rye translocation in wheat. Theor Appl Genet 90:105-112

Lookhart GL, Bean SR, Graybosch R, Chung OK, MorenaSevilla B, Baenziger S (1996) Identification by highperformance capillary electrophoresis of wheat lines containing the 1AL.1RS and the 1BL.1RS translocation. Cereal Chem 73(5):547-550

Seifers DL, Martin TJ, Harvey TL, Gill BS (1995) Temperature sensitivity and efficacy of wheat streak mosaic virus resistance derived from Agropyron intermedium. Plant Dis 79:1104-1106

Sharp GL, Martin JM, Lanning SP, Blake NK, Brey CW, Sivamani E, Qu R, Talbert LE (2002) Field evaluation of 
transgenic and classical sources of wheat streak mosaic virus resistance. Crop Sci 42:105-110

Steel RGD, Torrie JH (1980) Principles and procedures of statistics. McGraw-Hill Book Company, New York, NY, USA

Talbert LE, Bruckner PL, Smith LY, Sears R, Martin TJ (1996) Development of PCR markers linked to resistance to wheat streak mosaic virus in wheat. Theor Appl Genet 93:463-467
Wells DG, Wong RS, Lay CL, Gardner WS, Buchenau GW (1973) Registration of CI 15092 and CI 15093 wheat germplasm. Crop Sci 13(6):776

Wells DG, Kota RS, Sandhu HS, Gardner WS, Finney KF (1982) Registration of one disomic substitution line and five translocation lines of winter wheat germplasm resistant to Wheat Streak Mosaic Virus. Crop Sci 22(6):1277 